\title{
Review
}

Interational Axchives of
Allergy
Immunology

Published online: March 20, 2015

DOI: 10.1159/000375401

\section{Reactive Oxygen Species in Psoriasis and Psoriasis Arthritis: Relevance to Human Disease}

\author{
la Khmaladze Kutty Selva Nandakumar Rikard Holmdahl \\ Division of Medical Inflammation Research, Department of Biochemistry and Biophysics, Karolinska Institutet, \\ Stockholm, Sweden
}

\section{Key Words}

Psoriasis · Inflammation - Keratinocytes · Mouse models .

Reactive oxygen species

\begin{abstract}
Psoriasis (Ps) is a chronic, immune-mediated, skin inflammatory disease affecting up to $3 \%$ of the population worldwide. Different environmental triggers initiate this complex multifactorial syndrome. Many individuals affected by Ps (6-26\%) develop inflammatory disease in other organs, often in the joints as in psoriasis arthritis (PsA). Animal models that reflect the typical Ps syndrome, including both skin and joint pathology as in Ps and PsA, are valuable tools for dissecting disease pathways leading to clinical manifestations. In this context, we developed a new acute Ps and PsA-like disease model that appears after exposure to Saccharomyces cerevisiae mannan in certain mouse strains. The disease was found to be triggered by mannan-activated macrophages, leading to the activation of a pathogenic interleukin-17 pathway involving innate lymphocytes. Interestingly, the production of reactive oxygen species protected the mice from the triggering of this pathway and ameliorated Ps and PsA development.

(c) 2015 S. Karger AG, Basel
\end{abstract}

\section{Introduction}

Psoriasis (Ps) is a chronic, immune-mediated, skin inflammatory disease affecting up to $3 \%$ of the worldwide population with an equal sex distribution [1]. Different environmental triggers like infection (from bacteria, fungi and viruses) $[2,3]$, medications (lithium, antimalarials and nonsteroidal anti-inflammatory drugs) $[2,4,5]$, obesity [6] and stress [7] initiate or worsen this complex, multifactorial syndrome in genetically prone individuals. Ps patients are at a great risk of developing a number of comorbid conditions including diabetes mellitus, hypertension, coronary heart disease, inflammatory bowel disease, lymphoma and depression [8]. In addition, disorders involving musculoskeletal structures, the eyes and the gut are also common in these patients $[9,10]$.

\section{Clinical Characteristics}

Ps is usually manifested as erythematous, thickened plaques with silvery scales in the skin. Histopathologically, it is characterized by acanthosis (epidermal thickening) due to increased proliferation of keratinocytes with

\section{KARGER 125}

(c) 2015 S. Karger AG, Base

$1018-2438 / 15 / 1662-0135 \$ 39.50 / 0$ 


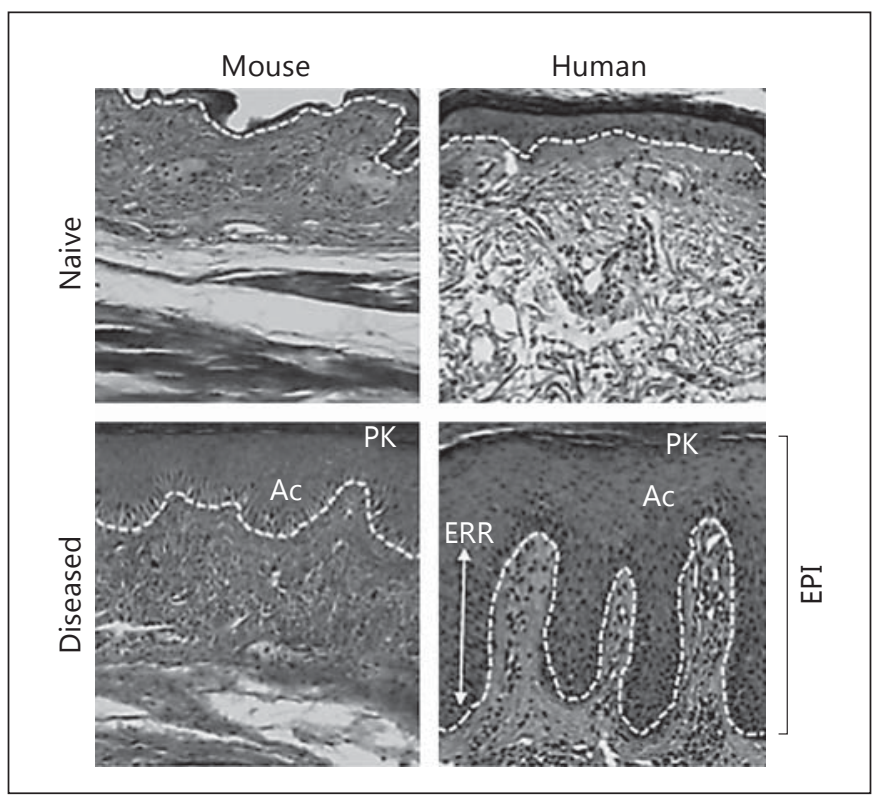

Fig. 1. Ps histopathology. Ac = Acanthosis; EPI = epidermis; $\mathrm{ERR}=$ elongated rete ridges; $\mathrm{PK}=$ parakeratosis. The dashed line indicates the border between the epidermis and the dermis.

elongated rete-like ridges protruding downward into the dermis. Incomplete maturation of epidermal keratinocytes results in an abnormal retention of nuclei in the stratum corneum, denoted as parakeratosis (the presence of nuclei in the cornified layer) and inflammatory infiltrates in the epidermis (fig. 1) and the dermis [11]. Erythema of Ps skin lesions is due to the increased dilation of elongated blood vessels in the papillary dermal region. Endothelial cells are also activated in Ps lesions via mechanisms dependent on ICAM-1 (intracellular adhesion molecule), VCAM-1 (vascular cell adhesion molecule) and E-selectin (CD62E) [12].

\section{Genetics}

Population-based studies show higher disease inheritance in first- and second-degree relatives compared to in the general population [13]. However, the concordance rate reaches $70 \%$ in monozygotic twins [14], arguing for the influence of environmental factors on disease manifestations. Classic genome-wide linkage analysis has mapped the PSORS1 (psoriasis susceptibility 1) locus as a major genetic determinant [15]. PSORS1 is located on chromosome 6 in the major histocompatibility complex (MHC) region spanning within the class I telomeric part of HLA-B. It accounts for up to $50 \%$ of the inheritability of Ps [16]. HLA-Cw6, an associated variant of HLA-C, was identified as the susceptibility allele within the PSORS1 region [17]. In 1985, nonpustular Ps was suggested to be divided in two subtypes: type 1, which usually develops before 40 years of age and has a strong family history associated with the HLA-Cw6 haplotype, and type 2 , which is noninheritable and develops after 40 years of age [18-21]. The presence of the HLA-Cw*0602 allele is correlated with an early onset and more severe Ps, and was found in $100 \%$ of patients with guttate Ps $[22,23]$. Lately, a loss-of-function mutation in the gene encoding the interleukin (IL)-36 receptor antagonist (IL36RN) was found to be associated with pustular Ps [24]. Genome-wide association studies have identified loci with IL23R, LCE3C/3D, IL13, TNIP1/ANXA6, IL12B, CDKAL1, HLA-C, TNFAIP3, IL23A/STAT2 and ZNF313 to be common risk variants for Ps development. However, only $11.6 \%$ of Ps heritability was associated with these loci and, most importantly, the most dominant risk locus was $H L A-C$ which has a predictive capability stronger than that of the other 9 non-MHC loci combined, as discussed by Johnson-Huang et al. [14]. Moreover, sequence variants in the gene of IL-23R and its ligand IL12B conferred protection against Ps [25].

During inflammation, regulation of the gene-expression network is controlled by microRNAs (miRs) via interference with key inflammatory checkpoints [26]. It was shown that a distinct miRNA expression profile exists in Ps skin compared to healthy skin. For example, miR-203, miR-125b, miR-424 and miR-99a [26-29] regulate keratinocyte proliferation and differentiation and miR-21 is upregulated in psoriatic skin and suppresses T-cell apoptosis events [30]. The suppression of miR-31 (an miRNA overexpressed in Ps keratinocytes) in Ps skin alleviated inflammation by interfering with the cross-talk between keratinocytes and immune cells [31].

\section{Psoriasis Arthritis}

Ps arthritis (PsA) is an inflammatory skin disease with the additional involvement of the joints [32]. Due to the clinical similarities between PsA and rheumatoid arthritis, and between PsA and Ps (in the initial phase), it is important to have specific criteria for the diagnosis of PsA. The most widely used classification criteria for PsA are CASPAR (Classification Criteria for Psoriatic Arthritis), for which signs of inflammatory articular disease are required $[32,33]$. One of the CASPAR is that PsA is sero- 
negative (lacking high titers of rheumatoid factors) and occurs in 6-26\% of patients with chronic plaque-type Ps [32, 33]. In 1973, Moll and Wright [34] described 5 distinct patterns of PsA based on the clinical presentation and distribution of the joint disease: (1) asymmetric polyarthritis is the most common form, affecting the distal joints in an asymmetric fashion and involving only few joints (oligoarthritis), (2) symmetric polyarthritis is the peripheral joint disease, which is symmetrically distributed, (3) spondyloarthropathy includes sacroiliitis and ankylosis spondylitis, (4) predominant distal interphalangeal joint disease involves distal interphalangeal joints and may develop into (5) arthritis mutilans, with distal joint desorption [34].

In recent years, extensive research has provided novel insights into the mechanisms involved in both skin and joint inflammation. The main pathological changes in PsA are associated with skin inflammation, synovial inflammation, enthesitis (enthesial inflammation), tenosynovitis (tendon-sheath inflammation) and bone abnormalities. Until recently, it was thought that the genes susceptible to $\mathrm{Ps}$ without arthritis $(\mathrm{PsO})$ and to PsA are the same, but recent studies have shown the existence of a distinct genetic make-up between these two diseases. Different HLA alleles like HLA-B*08, HLA$B^{*} 27$, HLA-B*38 and HLA-C*06 have been found to be associated with PsA rather than with $\mathrm{PsO}$ [35]. In addition, the frequency of HLA-C*06:02 was shown to be lower in PsA patients than in $\mathrm{PsO}$ patients [36]. Recent association studies show that MICA*016 is linked with increased risk of Ps, while homozygosity for MICA*00801 is associated with PsA development in Ps patients independently of HLA [37]. Moreover, PsA individuals with HLA-B*27 or DQB1*02 were shown to have an increased risk of developing the most severe form of PsA, arthritis mutilans [38]. Recent studies of the single-nucleotide polymorphism $+489 \mathrm{~A}$ allele of the tumor-necrosis factor (TNF) a gene shows a trend of association with the response to PsA treatment with neutralizing antibodies to TNFa (etanercept), suggesting a role for the SNP +489 A allele in the susceptibility and severity of PsA [39]. Moreover, gene-expression profiling of peripheral blood cells suggests that innate immunity may be important in the pathogenesis of PsA, involving Toll-like receptor (TLR) signaling, NF- $\kappa B$, and various chromatin-remodeling complexes, and potential biomarkers of PsA in Ps patients being identified, such as NOTCH2NL, HAT1, CXCL10 and SETD2, which were associated with PsA irrespective of clinical differences between patients [40].

ROS in Experimental Psoriasis and PsA

\section{Animal Models of Ps and PsA}

\section{Spontaneous Models}

Some inbred mouse strains tend to develop joint lesions that could resemble some aspects of PsA, in particular when challenged under stress conditions. Male mice of the DBA/1 strains, when grouped after puberty, develop stress due to intermale aggressiveness and then develop a severe arthritis characterized by swollen joints, inflammation and enthesitis, a disease believed to be caused by an exaggerated healing response [41, 42]. There are also a number of spontaneous mutations causing Ps phenotypes. The flaky-skin mouse (Ttcfsn/Ttcfsn) [43] has a spontaneous mutation that induces increased squamous-cell proliferation, but these mice are unresponsive to corticosteroid treatment. However, their lesions do not express all the features of Ps [44]. Similarly, a spontaneous mutation in CPD (chronic proliferative dermatitis) in Sharpin ${ }^{c p d m} /$ Sharpin $^{c p d m}$ mice [45] induces skin lesions at the age of 5-6 weeks that are characterized by epidermal hyperplasia, hyperkeratosis, parakeratosis and necrotic keratinocytes; the dermis and epidermis are infiltrated by granulocytes and macrophages [45]. This model is mainly dependent on Th2 cytokines (IL-4, IL-5 and IL-13), but the mice responded to IL-12 treatment [46].

\section{Genetically Engineered Models}

$\mathrm{K} 5 . \mathrm{Stat} 3 \mathrm{C}$ is a genetically manipulated strain in which the signal transducer and activator of transcription 3 is constitutively activated in basal keratinocytes under the control of the keratin 5 (K5) promoter [47]. Ps-like skin inflammation in this model is dependent on keratinocytes and T cells, but as interdependent participants. In these mice, an external stimulus such as tape-stripping exaggerated Ps symptoms, similar to the 'Koebner phenomenon' [47]. CD18 $\beta 2$ integrin hypomorphic mice have a reduced expression of common $\beta 2$-chain of lymphocyte integrin adhesion molecules. On a $\mathrm{PL} / \mathrm{J}$ strain background, PL.129S7-Itgb2 $2^{\text {(tm1Bay) }}$ mice develop Ps-like skin inflammation with infiltrating lymphocytes, and have nonpsoriasiform epidermal hyperplasia together with a condition similar to PsA that is dominated by enthesitis [48-50]. The JunB/c-Jun epidermal inducible double-knockout mouse represents another model targeting epidermal keratinocytes. JunB is a component of the AP-1 transcription factor. The JunB gene is localized in the Ps susceptibility region PSORS6, and c-Jun is considered as an antagonist to JunB. Epidermal deletion of both JunB and c-Jun leads to the development of a Ps-like disease phenotype and arthritic lesions in mice, and $\mathrm{T}$ and

Int Arch Allergy Immunol 2015;166:135-149 137 
$B$ cells play a minor role in the etiology of the disease. Additionally, the deletion of TNFR-1 in JunB/c-Jun doublemutant mice does not prevent the development of the skin phenotype, suggesting that TNFR-1 signaling might be dispensable for the induction of the disease [51]. Zenz et al. [51] proposed a possible mechanism in which the abrogation of the JunB/activator protein 1 in keratinocytes triggers chemokine/cytokine expressions that are responsible for neutrophil and macrophage recruitment to the epidermis, leading to various PsA phenotypes. Thus, epidermal alterations are sufficient to initiate both cutaneous and articular diseases. Another PsA model by Bardos et al. [52] described and characterized PsA-like disease in 'humanized' (HLA-transgenic) mice lacking their own MHC. Animals of 4 transgenic lines (HLADR2.Ab ${ }^{0}, \mathrm{DR} 4 . \mathrm{Ab}^{0}, \mathrm{DQ} 6 . \mathrm{Ab}^{0}$ and DQ8.Ab ${ }^{0}$ ) developed severe PsA-like symptoms, such as hyperkeratosis and parakeratosis, nail deformities and bone resorption associated with significantly fewer CD4+ cells in the peripheral blood as well as reduced NK cell activity when they were compared to disease-resistant HLA-DR3.Ab ${ }^{0}$ transgenic mice. Mice overexpressing VEGF epidermally via the K14 promoter develop Ps-like inflammation including vascular, epidermal and inflammatory features with an increased infiltration of mast cells in the upper dermis as well as increased leukocyte rolling and adhesion in the postcapillary skin venules. This study showed that VEGF in the epidermis is sufficient to induce skin inflammation, and it provides a new insight by linking angiogenesis, mast-cell accumulation and leukocyte recruitment to the sites of inflammation [53]. In the epidermal-specific IKK2 knockout mouse, the deletion of IKK2, the catalytic subunit of the I $\kappa \mathrm{B}$ kinase complex necessary for NF$\kappa \mathrm{B}$ activation through proinflammatory signals, causes Ps-like cutaneous inflammation dependent on TNF signaling but not on $\alpha \beta \mathrm{T}$ cell-mediated inflammatory responses. This study suggests the important function of IKK2-mediated NF- $\kappa \mathrm{B}$ activity in the epidermal keratinocytes for the maintenance of immune homeostasis in the skin [54].

In another model, epithelial growth factors, such as TGF $\alpha$, KGF and TGF $\beta$ were genetically targeted via the K14 or K5 promoters to the basal epidermis, which resulted in acanthosis but with no inflammatory cell infiltrations. For this reason, growth-factor transgenic mice are not considered as optimal models of Ps pathogenesis, but are useful for understanding epidermal growth and differentiation events [55]. The keratin 14 promoter amphiregulin (AR) gene (K14-ARGE) was shown to induce early-onset and severe skin pathology characterized by hyperkeratosis with focal parakeratosis, acanthosis, lymphocyte and neutrophilic infiltration and vasodilation, suggesting that the aberrant epidermal expression of AR might play a critical role in the development of psoriatic lesions [56]. The K14-IL-17 $\mathrm{A}^{\text {ind/+ }}$ mouse is a relatively new Ps animal model, in which transgenic IL-17A expression is targeted to the skin after crossing the IL-17A ${ }^{\text {ind }}$ allele with the K14-Cre strain. These mice develop skin inflammation with many hallmark characteristics of human Ps including the dermal infiltration of effector $T$ cells, the formation of neutrophil microabscesses and hyperkeratosis. IL-17A expression in the skin resulted in upregulated granulopoesis and the migration of IL-6Rexpressing neutrophils into the skin [57]. Involucrin enhancer/promoter-dependent expression of human AR (INV-AR) in the suprabasal epidermis of transgenic mice also depicted Ps-like features. Histopathologically, the INV-AR mouse had epidermal hyperkeratosis, parakeratosis, acanthosis, an exaggerated dermal vasculature and infiltrated neutrophils and CD3+ T lymphocytes in the lesions [58]. Thus, epidermal AR expression is a possible mediator of cutaneous inflammation and also a potential trigger of both cutaneous Ps and PsA (fig. 2).

\section{Induced Models}

Imiquimod (IMQ), a topical application targeting TLR7/8, can induce and exacerbate IL-23/IL-17 axis-dependent Ps in mice. IMQ-induced, inflamed, scaly skin lesions resemble plaque-type Ps and show increased epidermal proliferation, abnormal differentiation, $\mathrm{CD} 4+\mathrm{T}$ cells, CD11c+ dendritic cells (DCs), plasmacytoid DCs and neutrophil infiltration, along with neoangiogenesis. Epidermal expression of IL-23, IL-17A and IL-17F and an increase in splenic Th17 cells were noted [59]. Recently, in an IMQ-induced Ps-like model, Ps disease was partially reduced and delayed but not abolished in the absence of IL-17RA with persisting signs of inflammation such as neutrophil and macrophage infiltrations within the skin [60]. Moreover, Shibata et al. [61] demonstrated IL-27-activated Th1-mediated responses in IMQ-induced Ps-like skin lesions. More recently, Yoshiki et al. [62] showed that IL-23 from Langerhans cells (LCs) was required for the development of IMQ-induced Ps-like dermatitis by the induction of IL-17A-producing $\gamma \delta \mathrm{T}$ cells.

Very recently, we developed a new disease model, in which a single intraperitoneal injection of Saccharomyces cerevisiae mannan induced Ps-like and PsA-like symptoms in mice. Reactive oxygen species (ROS) determined the nature of the developed disease. Erythema and edema 


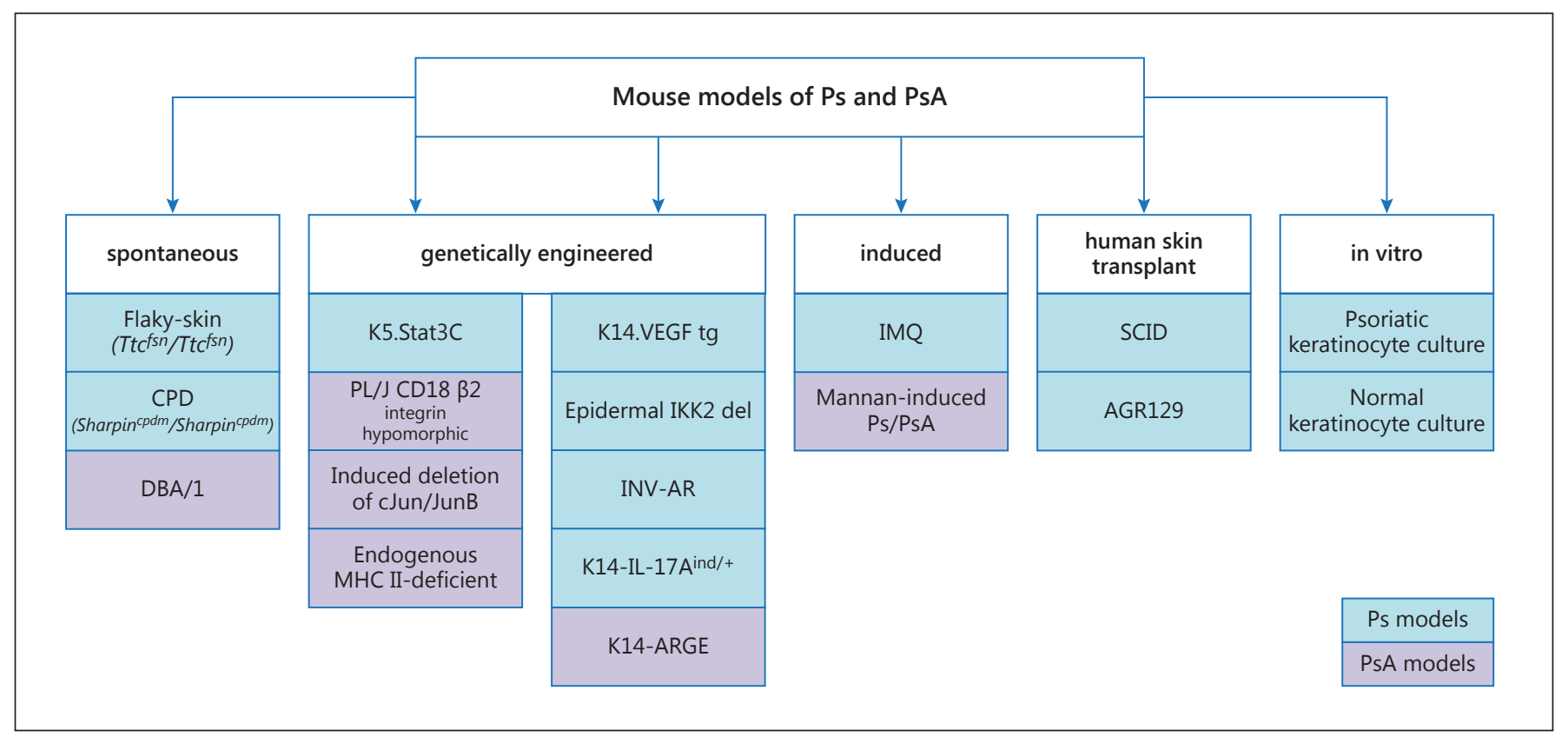

Fig. 2. Mouse models of Ps and PsA grouped as spontaneous, genetically engineered, induced, human skin transplant and in vitro models.

of joints started 1 day after the injection and reached maximum severity on days $4-5$, while skin scaling appeared from day 3 . This model depicts the inflammatory phase of PsA, where macrophages, $\gamma \delta$ T cells and IL-17A are the major contributors. Treatment with clodronate liposomes, anti-Ly6G and the neutralization of IL-17A and TNF $\alpha$ either completely blocked or significantly attenuated both joint and skin inflammation [63].

\section{Human Skin Transplant Models}

In human skin transplant models (xenotransplants), skin biopsy from Ps patients or in vitro cultured skin is transplanted into severe combined immunodeficient (SCID) mice. These mice lack $\mathrm{T}$ and $\mathrm{B}$ cells but contain functional neutrophils and mature natural killer (NK) cells [64]. In SCID mice, grafted tissues were well tolerated and psoriatic characteristics were maintained for several months in the transplants. AGR129 mice tolerated xenogenic grafts better than the SCID mice. AGR129 mice also lack T and B cells, but unlike SCID mice, they have immature NK cells [65]. Transplant rejection was reduced in these mice. Boyman et al. [65] demonstrated that human uninvolved psoriatic skin grafted onto AGR129 mice spontaneously developed psoriatic plaques. In fact, skin grafts developed a psoriatic phenotype in $90 \%$ of the grafted mice. The grafted-skin histopathology was comparable to Ps lesions. Inhibition of T cells with monoclonal antibodies, anti-CD3 and anti-TNFa treatments diminished Ps phenotypes [65]. Thus, activation and proliferation of skin-resident $\mathrm{T}$ cells are necessary and even sufficient to drive Ps inflammation (fig. 2).

\section{In vitro Models}

An alternative approach for studying Ps pathogenesis is by using in vitro models. In the in vitro system, epidermal keratinocytes obtained either from psoriatic or healthy individuals are grown at an air-liquid interface where they differentiate and mimic the morphology of the stratified squamous epidermis. Keratinocytes are then treated with different cytokines, such as IL-20 and IL-22, in order to develop psoriatic epidermis characteristics. This system enables the study of keratinocyte behavior towards different stimulation agents $[55,66]$ (fig. 2) and possible cross-talk events between keratinocytes and immune cells. Recent investigation of the interactions between keratinocytes and $\mathrm{T}$ cells in a three-dimensional microenvironment showed CD4+ T cell migration into the dermis, which initiated keratinocyte activation within 2 days [67]. The psoriasiform inflammation was also observed using Th1-polarized and Th17polarized CD4+ T cells. Treatment with anti-inflammatory drugs reduced the expression of proinflammatory 
cytokines and chemokines, leading to the suppression of the psoriasiform inflammation [67]. In vitro keratinocyte coculture also allowed for the characterizing of the cross-talk of cytokines and growth factors, where periostin tuned the magnitude of keratinocyte proliferation and differentiation by interacting with the paracrine IL1a/IL-6 loop [68].

\section{Immunopathology of Ps and PsA}

Both innate and adaptive immunity play a functional role in Ps pathology and in their interactions with keratinocytes. Keratinocytes have a key function in balancing skin homeostasis. Targeted deletion of cJun/JunB; K5.Stat3C in mice deregulates keratinocyte functions, leading to pathological immune responses resulting in different skin and/or joint pathologies. They also serve as sentinels of the skin and as a protective layer for the body against several invading pathogens. They express many types of innate immunity receptors like TLRs (TLR1-6, TLR9 and TLR10) recognizing PAMPS, and NLRs recognizing PAMPs and DAMPs (irritants and toxins). Activation of keratinocytes via TLR/NLR leads to predominantly Th1-type immune responses and the secretion of type I interferons (IFNs) [69]. Keratinocytes closely interact with skin-resident immune cells and thus contribute to inflammatory reactions. They produce antimicrobial peptides like psoriasin (S100A7), human $\beta$-defensins 2 and 3 and cathelicidin (LL-37) [70, 71], which form chemotactic gradients to attract immune cells to the skin tissue. Keratinocytes can also potentially secrete proinflammatory cytokines and chemokines, such as IL-1, IL-6, CXCL8, CXCL10 and CCL20 [71]. Recently, IL-19 production was found to be induced in keratinocytes by IL$17 \mathrm{~A}$, and this was further enhanced by TNFa and IL-22. Interestingly, IL-19 amplified many IL-17A effects on keratinocytes, including the induction of $\beta$-defensins, IL19, IL-23p19 and Th17 and neutrophil cells attracting chemokines [72]. In another study, keratinocyte overexpression of IL-17C promoted psoriasiform skin inflammation and Ps patients treated with etanercept rapidly decreased cutaneous IL-17C levels, likely suggesting the importance of IL-17C/TNFa-mediated inflammatory signaling in Ps pathogenesis [73]. A broad spectrum of cells that includes keratinocytes possesses binding sites for IL-8. Increased expression of epidermal IL-8 receptors has been observed in psoriatic skin [74]. Furthermore, keratinocytes are able to express MHC class II molecules induced by IFN- $\gamma$ and might act as nonprofessional anti- gen-presenting cells, thus contributing to the limitation of an ongoing inflammation by antigen-specific tolerization and/or activation of $\mathrm{T}$ cells [75].

\section{Innate Immunity}

Monocytes/macrophages are divided into three main populations based on their functional properties: proinflammatory M1, regulatory M2 and wound-healing macrophages [76]. Recently, Wang et al. [77] demonstrated that the inflammatory state in human blood monocytes could be stimulated by IL-17. In addition, IL-17 may also promote monocyte adhesion by inducing molecules such as ICAM-1, integrin $\alpha 4$, platelet/endothelial cell adhesion molecule 1 and CD99. M1 macrophages have a key function in both acute and chronic skin inflammation in animal models of Ps and PsA (the IKK, PL/J CD18 $\beta 2$ and mannan-induced Ps/PsA models), where macrophage depletion leads to resolution of skin inflammation $[63,78$, 79]. Psoriatic skin contains a large number of macrophage-secreting proinflammatory cytokines (IL-6, IL-12 and IL-23) [80, 81]. Macrophages are the major source of TNFa, which activates IL-17A-driven inflammatory pathways, leading to Ps/PsA-like inflammation in mice [63]. Hence, type I macrophages have good potential to be a therapeutic target in the future.

Neutrophils and mast cells are normally found in the infiltrations of psoriatic plaques, the main source for IL17 in the human skin. IL-17-positive mast cells and neutrophils are found at higher densities than IL-17-positive $\mathrm{T}$ cells in Ps lesions [82]; however, it is still debatable whether the positive staining for IL-17 in these cell types is due to its secretion or uptake from the milieu. In the mannan-induced Ps/PsA model, granulocyte infiltration has been observed in psoriatic skin and in the peritoneal cavity. Anti-Ly6G treatment suppressed both dermatitis and arthritis [63].

DCs are also sentinels of the immune system that bridge innate and adaptive immunity. They are normally found in both the layers of the skin: as LCs in the epidermis and myeloid and plasmacytoid DCs in the dermis. Another specialized subgroup of dermal DCs called TIPDCs, producing IFN- $\alpha$ and inducible nitric oxide synthase (iNOS) are also present in the skin. In human Ps tissue, the majority of CD11c+ cells produce iNOS [83]. Existing data on the frequency of LCs in Ps skin are inconsistent, but in the dermis, an increased number of $\mathrm{CD} 11 \mathrm{c}+$ myeloid DCs secreting the proinflammatory cytokines IL-12 and IL-23 can be found. These myeloid DCs 
might be the immigrant cells derived from circulating DC precursors that migrate and are trapped in the skin in response to the chemoattraction [83] induced by antimicrobial peptides and chemokine production by keratinocytes [71]. The numbers of plasmacytoid DCs are also significantly increased in Ps skin and are mainly activated via TLR signaling pathways. Large amounts of IFN- $\alpha$ are produced by plasmacytoid DCs in response to self-DNA/ LL-37 complexes targeting TLR9 or self-RNA/LL-37 complexes recognizing TLR7 and TLR8. Self-DNA/RNA fragments are released by the dying cells in the skin [84, 85]. Additionally, it was shown that alefacept (a CD2binding fusion protein) therapy reduces activated DCs and inflammatory gene expression in the tissue; this finding supports the involvement of DCs in Ps pathogenesis [86].

In healthy human skin, $\gamma \delta$ T cells are very rare, and it is still under debate whether they play a role in skin homeostasis or pathology. There are different subsets of $\gamma \delta$ $\mathrm{T}$ cells residing in different compartments of the mouse skin. One subset of dermal $\gamma \delta$ T cells expresses IL-7R, CCR6 and retinoic acid-related orphan receptor $\gamma \mathrm{t}$ $(\mathrm{ROR} \gamma \mathrm{t})$, which is different from the classic $\mathrm{V} \gamma 5 \mathrm{~V} \delta 1+$ DETC subset of $\gamma \delta$ T cells producing IFN- $\gamma[87,88]$. Mouse IL-17-producing $\gamma \delta$ T cells were shown to be important in IMQ-induced Ps and mannan-induced Ps/PsA models $[63,89]$. In the IMQ model, opposing effects of IL-15 and IL-15Ra were shown in psoriasiform skin inflammation, where IL-15 was responsible for the expansion of IL-17-producing $\gamma \delta$ (and $\alpha \beta$ ) T cell populations and was inhibited by keratinocyte-derived soluble IL-15 receptor antagonist [90]. Furthermore, CCR6 was required for the epidermal trafficking of $\gamma \delta$ T cells in the IL23-induced model of psoriasiform dermatitis [91]. Recent investigations show that IL-23 from LCs was necessary for the development of IMQ-induced Ps-like dermatitis via the induction of IL-17A-producing $\gamma \delta$ T cells [62]. Ps severity in CD18 $\beta 2$ integrin hypomorphic mice correlates with the loss of skin-resident $\mathrm{V} \gamma 5+\mathrm{T}$ cells and the concurrent skin infiltration of IL-17- and IL-22-producing dermal $\gamma \delta$ T cells. Thus, using different animal models of Ps, it is possible to clearly determine the important contribution of $\gamma \delta$ T cells in the inflammation of the skin.

\section{Adaptive Immunity}

T cells are considered to be the major mediators of Ps, where T-cell-mediated pathomechanisms lead to a large spectrum of regulatory mediators including cytokines, growth factors and lipid mediators, which are abnormally expressed in psoriatic skin [92]. Both lymphocyte inhibition and T-cell-specific immunosuppressive (cyclosporine) treatment lead to the clinical improvement of patients $[93,94]$. Some patients do not respond to treatment with T-cell-immunosuppressive medications, which might argue for different $\mathrm{T}$ cell-independent pathways in Ps development. This statement is supported by recent findings using mannan-induced inflammation, where $\alpha \beta \mathrm{T}$ cells had a negligible role in joint pathology [63]. The presence of IL-12 cytokines in the psoriatic plaques suggested dominant Th1-driven pathological events. However, another cytokine, IL-23, discovered later, was found to be crucial for disease development. This cytokine has a 19 protein paired to the IL-12 p40 subunit. In psoriatic skin, levels of the IL-23 p19 and p40 subunits, but not the IL-12 p35 subunit, increase significantly [95]. Ustekinumab binds specifically to IL-12/IL-23p40 and thus effectively neutralizes their biological activity. Recent findings imply that ustekinumab treatment improves Ps without suppressing tumor antigen-specific cytotoxic $\mathrm{T}$ lymphocytes, supporting clinical trials showing no increased incidence of malignancies with ustekinumab treatment [96]. IL-23 has been shown to activate $\mathrm{T}$ cells expressing a different cytokine profile such as IL-17A and IL-17F (termed Th17 cells) and an IL-22-expressing T-cell subset (called Th22). Both Th17 and Th22 cells require IL-23 for their expansion/maintenance and are implicated in Ps pathogenesis [97-99]. Thus IL-23-mediated skin inflammation is IL-17A-dependent, which in turn activates keratinocytes and leads to further production of inflammatory mediators; this all helps in maintaining the psoriatic lesions [99]. Th17 cells are rarely found at inflammatory sites in comparison with other T-cell subsets; this can be explained by the finding that Th17 cells rapidly shift into the Th1 phenotype in the presence of IL-12 and/or TNFa and they also possess self-regulatory mechanisms limiting their own expansion [100]. Different models of Ps are available to understand such disease pathology. The IL-22-overexpressing transgenic mouse has aberrant skin phenotypes mimicking Ps [101] and epidermal hyperplasia and macrophage infiltration in the dermis. It was shown that in the absence of IL-22, IL-23-mediated dermal inflammation was reduced significantly [102]. Recently, in the IMQ-induced psoriasiform skin inflammation model, skin pathologies were found to be almost absent after daily applications of IMQ in IL-22-deficient mice and also in mice treated with blocking anti-IL-22 antibodies [103]. Since IL-22 
neutralization does not induce considerable improvements in the majority of Ps patients [104], the precise therapeutic potential of this cytokine for these patients has still to be clarified.

Recently, a novel type of Th cells, designated as Th9, was identified, but little information is available about these cells in humans. Recently, Schlapbach et al. [105] showed that most of the memory Th9 cells are skin-tropic or skin-resident. Human Th9 cells coexpress TNFa and granzyme B, lack coproduction of Th1/Th2/Th17 cytokines and are specific to Candida albicans. IL-9-producing $\mathrm{T}$ cells are increased in the skin lesions of Ps, suggesting that they may contribute to human inflammatory skin disease. IL-9 is necessary for the efficient production of IFN- $\gamma$, IL-9, IL-13 and IL-17 by skin-tropic T cells. This study suggests that human Th9 cells may have a protective function against extracellular pathogens, but anomalous activation of these cells may contribute to inflammatory diseases of the skin.

\section{ROS in Psoriasis}

ROS and reactive nitrogen species (RNS) are oxygenderived reactive molecules, free radicals and nitrogencontaining oxidants with one or more uncoupled electrons. ROS generation as a byproduct occurs with mitochondria, peroxisomes, cytochrome $\mathrm{P} 450$ and other cellular elements. The phagocyte nicotinamide adenine dinucleotide phosphate (NADPH) oxidase was the first identified example of a system that generates ROS not as a byproduct, but rather as the primary function of the enzyme system. The phagocyte NOX family of NADPH oxidases consists of NOX complexes (NOX1-5) and dual oxidase complexes (DUOX1-2) [106]. These enzymes participate in ROS generation by transporting electrons across the plasma membrane. It was originally thought that only phagocytic cells were responsible for ROS production as part of the defense mechanism against invading pathogens, but it has also been demonstrated that ROS have a role in cell signaling including apoptosis, gene expression and the activation of cell signaling cascades [107]. Overproduction or inadequate removal of ROS can result in oxidative stress, leading to cell and tissue pathological changes due to damage to lipids, proteins and DNA [108]. In 1957, Berendes et al. [109] described a rare syndrome, triggered by pyogenic infections, now referred to as chronic granulomatous disease (CGD), caused by the absence of respiratory burst in the phagocytes. Patients with this genetic disorder suffer from life-threaten- ing infections $[110,111]$. CGD patients have mutations in all of the subunits of NOX complexes [112, 113]. An insufficient antioxidant system, together with increased levels of ROS, leads to pathological changes in cells and tissues, i.e. in inflammatory skin conditions [114]. Oxidative stress is believed to be a key factor in the pathogenesis of Ps [108]. Polymorphonuclear infiltrates in the dermis of psoriatic lesions were observed previously [115]. ROS discharged by keratinocytes, fibroblasts and endothelial cells might have chemotactic effects on neutrophils [116], and their accumulation in psoriatic lesions may cause abundant superoxide $\left(\mathrm{O}_{2}^{-}\right)$production during phagocytic processes [117].

\section{The Phagocyte NADPH Complex}

In a resting condition, the catalytic core of the phagocyte NADPH complex is composed of an enzymatic part, i.e. flavocytochrome b558, which consists of membrane integrated glycoprotein, gp91phox (NOX2) and p22phox protein. These jointly make up the central component of $\mathrm{NADPH}$ oxidase (fig. 3a) [118]. The phagocyte NADPH complex also contains four cytosolic components denoted as Ncf1 (p47phox), Ncf2 (p67phox), Ncf4 (p40phox) and the small G-protein Rac1 (or Rac2) [119], which play a regulatory role (fig. $3 \mathrm{a}$ ). In the resting state, this cytosolic Phox-protein complex is inactive due to Ncf1 autoinhibited conformation. Upon activation (exposure to microbes or inflammatory mediators), there is an exchange of guanosine diphosphate for guanosine triphosphate on Rac, leading to its activation. In addition, p47phox becomes heavily phosphorylated, releasing autoinhibitory confirmation, which enables the whole Phox-protein translocation and binding to flavocytochrome b558 [120]. The active enzyme complex transports electrons from cytoplasmic NADPH to extracellular or phagosomal oxygen to generate ROS superoxide $\left(\mathrm{O}_{2}^{-}\right)$molecules (fig. 3b).

\section{ROS/RNS Generation}

ROS and RNS are derived from the NOX/DUOX enzymes. $\mathrm{O}_{2}^{-}$is generated by the NOX enzymes and can be converted to hydrogen peroxide $\left(\mathrm{H}_{2} \mathrm{O}_{2}\right)$, either spontaneously or by the action of superoxide dismutase (SOD). Alternatively, it can react with $\mathrm{NO}$ to produce peroxynitrite $\left(\mathrm{ONOO}^{-}\right) \cdot \mathrm{H}_{2} \mathrm{O}_{2}$ generated by the DUOX enzymes or by the dismutation of $\mathrm{O}_{2}^{-}$can be scavenged by the an- 


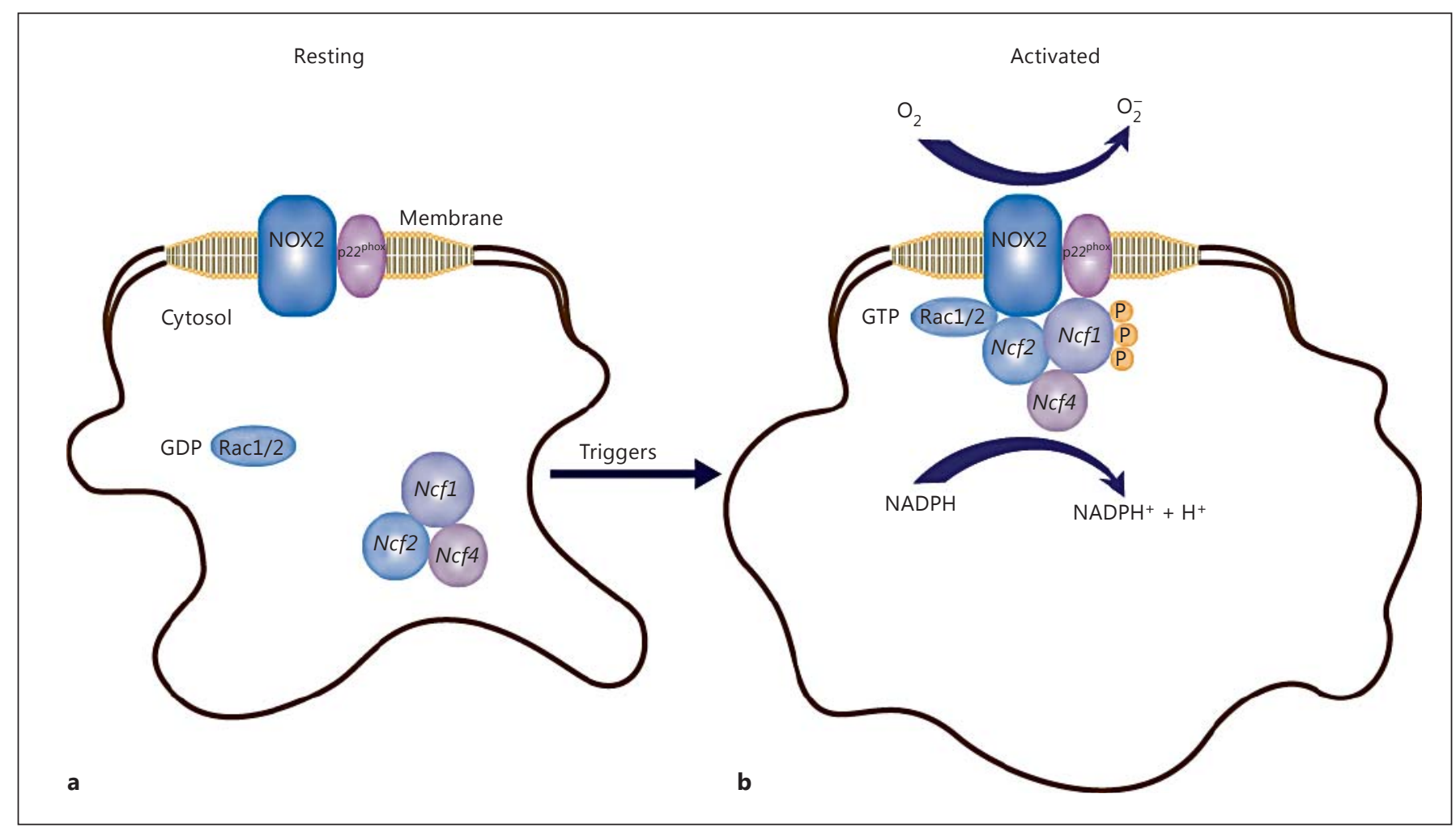

Fig. 3. The NADPH complex consists of the membrane flavocytochrome b558 (NOX2 and p22 $2^{\text {phox }}$ protein) and the cytosolic components Ncf1, Ncf2, Ncf4 and the small G-protein Rac1 or Rac2 (a). Upon activation, there is an exchange of guanosine diphosphate (GDP) to guanosine triphosphate (GTP) on Rac, leading to

tioxidants catalase (Cat) or glutathione peroxidase (GPx) and form $\mathrm{H}_{2} \mathrm{O}$ and $\mathrm{O}_{2}$, be partially reduced to generate hydroxyl radical $(\mathrm{OH})$ by the $\mathrm{Fe}^{3+}$-catalyzed Haber-Weiss and Fenton reactions or react with chloride in a reaction catalyzed by myeloperoxidase, resulting in the formation of hypochlorous acid (HOCl; fig. 4) [121].

\section{Cellular Antioxidants}

Antioxidants are compounds that will provide electrons to free radicals to neutralize them. It has been suggested that there is an insufficient antioxidant system in the pathogenesis of Ps. SOD, GPx and Cat are the most important enzymes in the antioxidant system. SOD protects cells from the toxic effects of $\mathrm{O}_{2}^{-}$radicals. Various results have been obtained in earlier studies on SOD activity in psoriatic patients. Therond et al. [122] found substantial SOD activity in the fibroblasts and erythrocytes of Ps patients, while another study showed lower its activation. Phosphorylated Ncf1 releases the autoinhibitory confirmation and enables the whole complex translocation to flavocytochrome b558. The active enzyme complex transports electrons from cytoplasmic NADPH to extracellular or phagosomal oxygen to generate ROS.

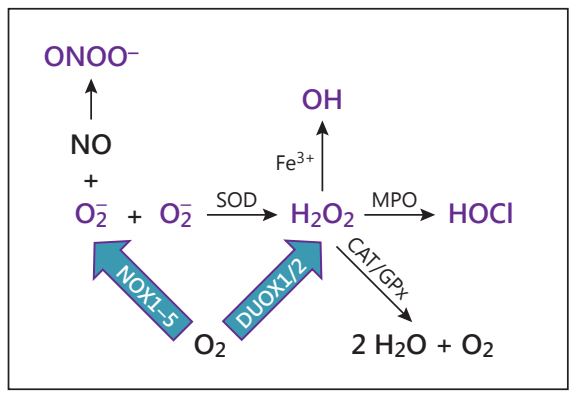

Fig. 4. Schematic representation of ROS/RNS generation in macrophages, where $\mathrm{O}_{2}^{-}, \mathrm{NO}$, peroxynitrite $\left(\mathrm{ONOO}^{-}\right), \mathrm{H}_{2} \mathrm{O}$, hydroxyl radical $(\mathrm{OH})$ and hypochlorous acid $(\mathrm{HOCl})$ are formed by the action of the NOX1-5, DUOX1/2 enzymes and antioxidants like SOD, Cat, GPx, myeloperoxidase (MPO) and $\mathrm{Fe}^{3+}$.

SOD activity in the psoriatic group and suggested that SOD activity is lower in Ps because of an insufficiency in the antioxidant system [123]. Several other studies have also reported suppressed SOD activity in neutrophils 
$[124,125]$. Extracellular SOD has antichemotactic activities and has been detected at low levels in Ps lesions. ECSOD knockout mice develop severe IL-23-mediated skin inflammation. The infiltration of immune cells at IL-23 injection sites and the expression of proinflammatory cytokines and chemokines are more elevated in these mice [126]. Interestingly, the IQM-induced mouse model shows an aberrant antioxidant system, with increased levels of myeloperoxidase and oxidative stress but less SOD activity. This model may thus be useful for studying the pathogenic role of redox imbalance in Ps [127]. The clinical response to efalizumab correlates with the antioxidant enzyme GPx activity in the blood cells, suggesting high hydrogen peroxide levels with Ps persistence [128]. Similarly, decreased neutrophil GPx activity has been observed in chronic plaque-type Ps [129]. Notably, erythrocyte Cat activity is significantly higher in psoriatic subjects than in controls $[123,130]$. All of these findings support the general hypothesis that disturbance in the oxidant-antioxidant system may play an important role in the pathogenesis of Ps.

\section{Protective Nature of ROS}

Recent studies implicate ROS as playing an immunoregulatory role in inflammatory diseases; this is in contrast to the traditional view of their damaging effects. As described previously, CGD patients are more prone to the development of different autoimmune diseases. Elevated levels of ROS due to defects in GPx1 and Cat in $\mathrm{GPx}^{-1-} \times \mathrm{Cat}^{-/-}$mice conferred resistance to DSS-induced colitis. The administration of $\mathrm{N}$-acetylcysteine reduced Treg functions and made these mice susceptible to colitis [131]. Similarly, GPx1 deficiency in mice attenuated allergen-induced airway inflammation by suppressing Th2 and Th17 cell development [132]. Ablation of peroxiredoxin (a nonenzymatic cellular antioxidant) in mice attenuated colitis by increasing Treg functions [133]. Most recently, lowered ROS levels were associated with chronic colitis in $\mathrm{Ncf} 1 / \mathrm{p} 47^{\text {phox }}$-mutant mice, mediated by local accumulation of peroxynitrites, proinflammatory cytokines and lymphocytes and systemic immune deregulation, similar to in CGD patients [134]. These studies implicate an association of ROS level with $\mathrm{T}$ cell/Treg responsiveness. Previously, reduced ROS levels were associated with the development of autoimmune arthritis and encephalomyelitis using the $N c f 1$ gene-mutated mouse strain, in which the $\mathrm{Ncf} 1 / \mathrm{p} 47^{\text {phox }}$ subunit of the NOX2 complex was dysfunctional [135]. Ncf1 has been identified as a regulator of autoimmune arthritis in rodents [136]. Decreased ROS levels in these animals have been associated with an increased number of cell surface thiol groups on T cells, significantly enhancing the arthritogenicity of the cells [137]. Most importantly, macrophage-specific ROS production has been reported to suppress $\mathrm{T}$ cell responses and arthritis development [138]. It was previously suggested that Tregs under reduced ROS conditions are hypofunctional [139], and recently, Treg hyperfunctionality in elevated levels of ROS in an IMQ-induced Ps dermatitis model was observed [140]. Treg hyperfunctionality with high levels of ROS is suggested to operate as a compensatory mechanism to overcome the damaging effects of ROS and thereby decrease Ps disease activity [140]. Thus, the restoration of impaired Treg functions could be a possible therapeutic strategy for Ps patients.

Similarly, successful treatment of psoriasis vulgaris patients by hyperbaric oxygen therapy, which increases cellular ROS [141], was demonstrated previously [142]. Furthermore, hyperbaric oxygen therapy attenuated IMQ-induced Ps dermatitis whereas $\mathrm{N}$-acetylcysteine aggravated it [140]. Recent studies also demonstrated the effect of photo(chemo)therapy in increasing Treg functions and reducing circulating Th17 cells [143]. Since it is known that phototherapy generates elevated ROS levels [144], it can be considered that elevated ROS might be the driving mechanism for Treg hyperfunctionality.

\section{Ncf1 as a Regulator of Mannan-Induced Ps/PsA in Mice}

Recently, we observed the immunoregulatory role of monocyte/macrophage-derived ROS in $\mathrm{Ncfl}^{\mathrm{mlj} / \mathrm{mlj}} \cdot \mathrm{MN}+$ mice, which expresses functional $N c f 1$ in macrophages [63]. We measured mannan-stimulated ROS/RNS at the cell (blood granulocytes) and organ (hind paws) levels in $\mathrm{B} 10 \mathrm{Q}, \mathrm{B} 10 \mathrm{Q} \cdot N c f 1^{\mathrm{mlj} / \mathrm{m} 1 \mathrm{j}} \cdot \mathrm{MN}+$ and B10Q.Ncf1 ${ }^{\mathrm{mlj} / / \mathrm{m} 1 \mathrm{j}}$ mice, where secreted ROS correlated with relatively milder peripheral-joint arthritis phenotypes and ROS deficiency promoted a more aggressive disease. Similarly, $\beta 1,3$-glucan of Alcaligenes faecalis-induced ROS from monocytes was also shown to suppress innate inflammation [145]. Moreover, the protective function of ROS has been shown in other human skin diseases like scleroderma [146].

Hence, the normal production of ROS by a functional NOX2 seems to be critical for attenuating Ps and arthritis phenotypes in mice [63], but the mechanism whereby 
ROS protection operates at the cellular and molecular level needs to be investigated further. It is most likely different from in autoimmune arthritis where $\alpha \beta \mathrm{T}$ cells play a critical role under the regulatory control of macrophageproduced ROS [138], and also different from the IMQ-Ps dermatitis model where the ROS-mediated prevention of Ps operates through enhanced expression of indoleamine 2,3-dioxygenase and Treg activity [140].

\section{Concluding Remarks}

PsA and PsO are common but complex diseases that have so far escaped a detailed understanding of their causative pathways. However, new genetic findings, the development of effective treatments of established disease and the establishment of useful animal models will be valuable for future research. Using these tools, understanding the cause and pathogenic mechanisms involved is within reach, and will facilitate the development of treatments to not only ameliorate but also prevent and cure these diseases.

\section{References}

1 Stern RS, Nijsten T, Feldman SR, Margolis DJ, Rolstad T: Psoriasis is common, carries a substantial burden even when not extensive, and is associated with widespread treatment dissatisfaction. J Investig Dermatol Symp Proc 2004;9:136-139.

2 Fry L, Baker BS: Triggering psoriasis: the role of infections and medications. Clin Dermatol 2007;25:606-615.

3 Morar N, Willis-Owen SA, Maurer T, Bunker CB: HIV-associated psoriasis: pathogenesis, clinical features, and management. Lancet Infect Dis 2010;10:470-478.

4 Tsankov N, Angelova I, Kazandjieva J: Druginduced psoriasis. Recognition and management. Am J Clin Dermatol 2000;1:159-165.

5 Raychaudhuri SP, Jiang WY, Raychaudhuri SK: Revisiting the Koebner phenomenon: role of NGF and its receptor system in the pathogenesis of psoriasis. Am J Pathol 2008;172: 961-971.

6 Neimann AL, Shin DB, Wang X, Margolis DJ, Troxel AB, Gelfand JM: Prevalence of cardiovascular risk factors in patients with psoriasis J Am Acad Dermatol 2006;55:829-835.

7 Picardi A, Abeni D: Stressful life events and skin diseases: disentangling evidence from myth. Psychother Psychosom 2001;70:118136.

8 Ni C, Chiu MW: Psoriasis and comorbidities: links and risks. Clin Cosmet Invest Dermatol 2014;7:119-132.

9 Scarpa R, Soscia E, Peluso R, Atteno M, Manguso F, Del Puente A, Spano A, Sirignano C, Oriente A, Di Minno MN, Iervolino S, Salvatore M: Nail and distal interphalangeal joint in psoriatic arthritis. J Rheumatol 2006;33: 1315-1319.

10 Ritchlin C: Psoriatic disease - from skin to bone. Nat Clin Pract Rheumatol 2007;3:698706.

11 Nestle FO, Kaplan DH, Barker J: Psoriasis. N Engl J Med 2009;361:496-509.

12 Lowes MA, Bowcock AM, Krueger JG: Pathogenesis and therapy of psoriasis. Nature 2007; 445:866-873.
13 Farber EM, Nall ML: The natural history of psoriasis in 5,600 patients. Dermatologica 1974; 148:1-18.

14 Johnson-Huang LM, Lowes MA, Krueger JG: Putting together the psoriasis puzzle: an update on developing targeted therapies. Dis Model Mech 2012;5:423-433.

15 Trembath RC, Clough RL, Rosbotham JL, Jones AB, Camp RD, Frodsham A, Browne J, Barber R, Terwilliger J, Lathrop GM, Barker $\mathrm{JN}$ : Identification of a major susceptibility locus on chromosome $6 \mathrm{p}$ and evidence for further disease loci revealed by a two-stage genome-wide search in psoriasis. Hum Mol Genet 1997;6:813-820.

16 Capon F, Munro M, Barker J, Trembath R: Searching for the major histocompatibility complex psoriasis susceptibility gene. J Invest Dermatol 2002;118:745-751.

17 Nair RP, Stuart PE, Nistor I, Hiremagalore R, Chia NV, Jenisch S, Weichenthal M, Abecasis GR, Lim HW, Christophers E, Voorhees JJ, Elder JT: Sequence and haplotype analysis supports HLA-C as the psoriasis susceptibility 1 gene. Am J Hum Genet 2006;78:827-851.

18 Henseler T, Christophers E: Psoriasis of early and late onset: characterization of two types of psoriasis vulgaris. J Am Acad Dermatol 1985;13:450-456.

19 Patel RV, Lebwohl M: In the clinic. Psoriasis Ann Intern Med 2011; 155:ITC2-1-ICT2-15; quiz ITC12-16.

20 Henseler T: The genetics of psoriasis. J Am Acad Dermatol 1997;37:S1-S11.

21 Levine D, Gottlieb A: Evaluation and management of psoriasis: an internist's guide. Med Clin North Am 2009;93:1291-1303.

22 Gudjonsson JE, Karason A, Antonsdottir AA, Runarsdottir EH, Gulcher JR, Stefansson K, Valdimarsson H: HLA-Cw6-positive and HLA-Cw6-negative patients with psoriasis vulgaris have distinct clinical features. J Invest Dermatol 2002;118:362-365.
23 Mallon E, Bunce M, Savoie H, Rowe A, Newson R, Gotch F, Bunker CB: HLA-C and guttate psoriasis. Br J Dermatol 2000;143:11771182.

24 Marrakchi S, Guigue P, Renshaw BR, Puel A, Pei XY, Fraitag S, Zribi J, Bal E, Cluzeau C, Chrabieh M, Towne JE, Douangpanya J, Pons C, Mansour S, Serre V, Makni H, Mahfoudh N, Fakhfakh F, Bodemer C, Feingold J, HadjRabia S, Favre M, Genin E, Sahbatou M, Munnich A, Casanova JL, Sims JE, Turki H, Bachelez $\mathrm{H}$, Smahi A: Interleukin-36-receptor antagonist deficiency and generalized pustular psoriasis. New Engl J Med 2011;365:620-628.

25 Capon F, Di Meglio P, Szaub J, Prescott NJ, Dunster C, Baumber L, Timms K, Gutin A, Abkevic V, Burden AD, Lanchbury J, Barker JN, Trembath RC, Nestle FO: Sequence variants in the genes for the interleukin-23 receptor (IL23R) and its ligand (IL12B) confer protection against psoriasis. Hum Genet 2007; 122:201-206.

26 Sonkoly E, Wei T, Janson PC, Saaf A, Lundeberg L, Tengvall-Linder M, Norstedt G, Alenius $\mathrm{H}$, Homey B, Scheynius A, Stahle M, Pivarcsi A: MicroRNAs: novel regulators involved in the pathogenesis of psoriasis? PLoS One 2007;2:e610.

27 Xu N, Brodin P, Wei T, Meisgen F, Eidsmo L, Nagy N, Kemeny L, Stahle M, Sonkoly E, Pivarcsi A: MiR-125b, a microRNA downregulated in psoriasis, modulates keratinocyte proliferation by targeting FGFR2. J Invest Dermatol 2011;131:1521-1529.

28 Ichihara A, Jinnin M, Yamane K, Fujisawa A Sakai K, Masuguchi S, Fukushima S, Maruo K, Ihn H: MicroRNA-mediated keratinocyte hyperproliferation in psoriasis vulgaris. $\mathrm{Br} \mathrm{J}$ Dermatol 2011;165:1003-1010.

29 Lerman G, Avivi C, Mardoukh C, Barzilai A, Tessone A, Gradus B, Pavlotsky F, Barshack I, Polak-Charcon S, Orenstein A, Hornstein E, Sidi Y, Avni D: MiRNA expression in psoriatic skin: reciprocal regulation of hsa-miR99a and IGF-1R. PLoS One 2011;6:e20916. 
30 Meisgen F, Xu N, Wei T, Janson PC, Obad S, Broom O, Nagy N, Kauppinen S, Kemeny L, Stahle M, Pivarcsi A, Sonkoly E: MiR-21 is upregulated in psoriasis and suppresses $\mathrm{T}$ cell apoptosis. Exp Dermatol 2012;21:312-314.

31 Xu N, Meisgen F, Butler LM, Han G, Wang XJ, Soderberg-Naucler C, Stahle M, Pivarcsi A, Sonkoly E: MicroRNA-31 is overexpressed in psoriasis and modulates inflammatory cytokine and chemokine production in keratinocytes via targeting serine/threonine kinase 40. J Immunol 2013;190:678-688.

32 Prey S, Paul C, Bronsard V, Puzenat E, Gourraud $\mathrm{PA}$, Aractingi $\mathrm{S}$, Aubin F, Bagot $\mathrm{M}$, Cribier B, Joly P, Jullien D, Maitre ML, Richard-Lallemand MA, Ortonne JP: Assessment of risk of psoriatic arthritis in patients with plaque psoriasis: a systematic review of the literature. J Eur Acad Dermatol Venereol 2010;24(suppl 2):31-35.

33 Coates LC, Conaghan PG, Emery P, Green MJ, Ibrahim G, MacIver H, Helliwell PS: Sensitivity and specificity of the classification of psoriatic arthritis criteria in early psoriatic arthritis. Arthritis Rheum 2012;64:3150-3155.

34 Moll JM, Wright V: Psoriatic arthritis. Semin Arthritis Rheum 1973;3:55-78.

35 Eder L, Chandran V, Pellett F, Shanmugarajah S, Rosen CF, Bull SB, Gladman DD: Differential human leucocyte allele association between psoriasis and psoriatic arthritis: a family-based association study. Ann Rheum Dis 2012;71:1361-1365.

36 Winchester R, Minevich G, Steshenko V, Kirby B, Kane D, Greenberg DA, FitzGerald O: HLA associations reveal genetic heterogeneity in psoriatic arthritis and in the psoriasis phenotype. Arthritis Rheum 2012;64:11341144.

37 Pollock R, Chandran V, Barrett J, Eder L, Pellett F, Yao C, Lino M, Shanmugarajah S, Farewell VT, Gladman DD: Differential major histocompatibility complex class I chain-related A allele associations with skin and joint manifestations of psoriatic disease. Tissue Antigens 2011;77:554-561.

38 Chandran V: Time to event and progressive multi-state analyses confirm the association between human leukocyte antigen alleles and the development of arthritis mutilans in patients with psoriatic arthritis. Proceedings of the 3rd World Congress of Psoriasis and Psoriatic Arthritis, Stockholm, June 2012.

39 Murdaca G, Gulli R, Spano F, Lantieri F, Burlando M, Parodi A, Mandich P, Puppo F: TNF-alpha gene polymorphisms: association with disease susceptibility and response to anti-TNF-alpha treatment in psoriatic arthritis. J Invest Dermatol 2014;134:2503-2509.

40 Pollock RA, Abji F, Liang K, Chandran V, Pellett FJ, Virtanen C, Gladman DD: Gene expression differences between psoriasis patients with and without inflammatory arthritis. J Invest Dermatol 2015;135:620-623.
41 Holmdahl R, Jansson L, Andersson M, Jonsson R: Genetic, hormonal and behavioural influence on spontaneously developing arthritis in normal mice. Clin Exp Immunol 1992;88: 467-472.

42 Corthay A, Hansson AS, Holmdahl R: T lymphocytes are not required for the spontaneous development of entheseal ossification leading to marginal ankylosis in the DBA/1 mouse. Arthritis Rheum 2000;43:844-851.

43 Sundberg JP, Beamer WG, Shultz LD, Dunstan RW: Inherited mouse mutations as models of human adnexal, cornification, and papulosquamous dermatoses. J Invest Dermatol 1990;95:62S-63S.

44 Sundberg JP, France M, Boggess D, Sundberg BA, Jenson AB, Beamer WG, Shultz LD: Development and progression of psoriasiform dermatitis and systemic lesions in the flaky skin (FSN) mouse mutant. Pathobiology 1997;65:271-286.

45 HogenEsch H, Gijbels MJ, Offerman E, van Hooft J, van Bekkum DW, Zurcher C: A spontaneous mutation characterized by chronic proliferative dermatitis in C57BL mice. Am J Pathol 1993;143:972-982.

46 Kauffman CL, Aria N, Toichi E, McCormick TS, Cooper KD, Gottlieb AB, Everitt DE, Frederick B, Zhu Y, Graham MA, Pendley CE, Mascelli MA: A phase I study evaluating the safety, pharmacokinetics, and clinical response of a human IL-12 p40 antibody in subjects with plaque psoriasis. J Invest Dermatol 2004;123:1037-1044.

47 Sano S, Chan KS, Carbajal S, Clifford J, Peavey M, Kiguchi K, Itami S, Nickoloff BJ, DiGiovanni J: Stat 3 links activated keratinocytes and immunocytes required for development of psoriasis in a novel transgenic mouse model. Nat Med 2005;11:43-49.

48 Wang H, Peters T, Sindrilaru A, Kess D, Oreshkova T, Yu XZ, Seier AM, Schreiber H, Wlaschek M, Blakytny R, Rohrbein J, Schulz G, Weiss JM, Scharffetter-Kochanek K: TGFbeta-dependent suppressive function of Tregs requires wild-type levels of CD18 in a mouse model of psoriasis. J Clin Invest 2008;118: 2629-2639.

49 Bullard DC, Scharffetter-Kochanek K, McArthur MJ, Chosay JG, McBride ME, Montgomery CA, Beaudet AL: A polygenic mouse model of psoriasiform skin disease in CD18-deficient mice. Proc Nat Acad Sci USA 1996;93: 2116-2121.

50 Kess D, Peters T, Zamek J, Wickenhauser C, Tawadros S, Loser K, Varga G, Grabbe S, Nischt R, Sunderkotter C, Muller W, Krieg T, Scharffetter-Kochanek K: CD4+ T cell-associated pathophysiology critically depends on CD18 gene dose effects in a murine model of psoriasis. J Immunol 2003;171:5697-5706.

51 Zenz R, Eferl R, Kenner L, Florin L, Hummerich L, Mehic D, Scheuch H, Angel P, Tschachler E, Wagner EF: Psoriasis-like skin disease and arthritis caused by inducible epidermal deletion of Jun proteins. Nature 2005; 437:369-375.
52 Bardos T, Zhang J, Mikecz K, David CS, Glant TT: Mice lacking endogenous major histocompatibility complex class II develop arthritis resembling psoriatic arthritis at an advanced age. Arthritis Rheum 2002;46:24652475.

53 Detmar M, Brown LF, Schon MP, Elicker BM, Velasco P, Richard L, Fukumura D, Monsky W, Claffey KP, Jain RK: Increased microvascular density and enhanced leukocyte rolling and adhesion in the skin of VEGF transgenic mice. J Invest Dermatol 1998;111:1-6.

54 Pasparakis M, Courtois G, Hafner M, Schmidt-Supprian M, Nenci A, Toksoy A, Krampert M, Goebeler M, Gillitzer R, Israel A, Krieg T, Rajewsky K, Haase I: TNF-mediated inflammatory skin disease in mice with epidermis-specific deletion of IKK2. Nature 2002;417:861-866.

55 Danilenko DM: Review paper: preclinical models of psoriasis. Vet Pathol 2008;45:563-575.

56 Cook PW, Piepkorn M, Clegg CH, Plowman GD, DeMay JM, Brown JR, Pittelkow MR: Transgenic expression of the human amphiregulin gene induces a psoriasis-like phenotype. J Clin Invest 1997;100:2286-2294.

57 Croxford AL, Karbach S, Kurschus FC, Wortge S, Nikolaev A, Yogev N, Klebow S, Schuler R, Reissig S, Piotrowski C, Brylla E, Bechmann I, Scheller J, Rose-John S, Wunderlich FT, Munzel T, von Stebut E, Waisman A: IL-6 regulates neutrophil microabscess formation in IL-17A-driven psoriasiform lesions. J Invest Dermatol 2014;134:728-735.

58 Cook PW, Brown JR, Cornell KA, Pittelkow MR: Suprabasal expression of human amphiregulin in the epidermis of transgenic mice induces a severe, early-onset, psoriasis-like skin pathology: expression of amphiregulin in the basal epidermis is also associated with synovitis. Exp Dermatol 2004;13:347-356.

59 van der Fits L, Mourits S, Voerman JS, Kant M, Boon L, Laman JD, Cornelissen F, Mus AM, Florencia E, Prens EP, Lubberts E: Imiquimod-induced psoriasis-like skin inflammation in mice is mediated via the IL-23/IL17 axis. J Immunol 2009;182:5836-5845.

60 El Malki K, Karbach SH, Huppert J, Zayoud M, Reissig S, Schuler R, Nikolaev A, Karram K, Munzel T, Kuhlmann CR, Luhmann HJ, von Stebut E, Wortge S, Kurschus FC, Waisman A: An alternative pathway of imiquimod-induced psoriasis-like skin inflammation in the absence of interleukin-17 receptor A signaling. J Invest Dermatol 2013;133:441451.

61 Shibata S, Tada Y, Asano Y, Yanaba K, Sugaya M, Kadono T, Kanda N, Watanabe S, Sato S: IL-27 activates Th1-mediated responses in imiquimod-induced psoriasis-like skin lesions. J Invest Dermatol 2013;133:479-488. 
62 Yoshiki R, Kabashima K, Honda T, Nakamizo S, Sawada Y, Sugita K, Yoshioka H, Ohmori S, Malissen B, Tokura Y, Nakamura M: IL-23 from Langerhans cells is required for the development of imiquimod-induced psoriasislike dermatitis by induction of IL-17A-producing gammadelta T cells. J Invest Dermatol 2014;134:1912-1921.

63 Khmaladze I, Kelkka T, Guerard S, Wing K, Pizzolla A, Saxena A, Lundqvist K, Holmdahl M, Nandakumar KS, Holmdahl R: Mannan induces ROS-regulated, IL-17A-dependent psoriasis arthritis-like disease in mice. Proc Nat Acad Sci USA 2014;111:E3669-E3678.

64 Gudjonsson JE, Johnston A, Dyson M, Valdimarsson H, Elder JT: Mouse models of psoriasis. J Invest Dermatol 2007;127:12921308.

65 Boyman O, Hefti HP, Conrad C, Nickoloff BJ, Suter M, Nestle FO: Spontaneous development of psoriasis in a new animal model shows an essential role for resident T Cells and tumor necrosis factor-alpha. J Exp Med 2004;199:731-736.

66 Boniface K, Bernard FX, Garcia M, Gurney AL, Lecron JC, Morel F: IL-22 inhibits epidermal differentiation and induces proinflammatory gene expression and migration of human keratinocytes. J Immunol 2005; 174 : 3695-3702.

67 van den Bogaard EH, Tjabringa GS, Joosten I, Vonk-Bergers M, van Rijssen E, Tijssen HJ, Erkens M, Schalkwijk J, Koenen HJ: Crosstalk between keratinocytes and T cells in a 3D microenvironment: a model to study inflammatory skin diseases. J Invest Dermatol 2014; 134:719-727.

68 Taniguchi K, Arima K, Masuoka M, Ohta S, Shiraishi H, Ontsuka K, Suzuki S, Inamitsu M, Yamamoto K, Simmons O, Toda S, Conway SJ, Hamasaki Y, Izuhara K: Periostin controls keratinocyte proliferation and differentiation by interacting with the paracrine IL1alpha/IL-6 loop. J Invest Dermatol 2014;134: 1295-1304.

69 Miller LS, Modlin RL: Human keratinocyte Toll-like receptors promote distinct immune responses. J Invest Dermatol 2007;127:262-263.

70 Buchau AS, Gallo RL: Innate immunity and antimicrobial defense systems in psoriasis. Clin Dermatol 2007;25:616-624.

71 Nestle FO, Di Meglio P, Qin JZ, Nickoloff BJ: Skin immune sentinels in health and disease. Nat Rev Immunol 2009;9:679-691.

72 Witte E, Kokolakis G, Witte K, Philipp S, Doecke WD, Babel N, Wittig BM, Warszawska K, Kurek A, Erdmann-Keding M, Kunz S, Asadullah K, Kadin ME, Volk HD, Sterry W, Wolk K, Sabat R: IL-19 is a component of the pathogenetic IL-23/IL-17 cascade in psoriasis. J Invest Dermatol 2014;134:2757-2767.

73 Johnston A, Fritz Y, Dawes SM, Diaconu D, Al-Attar PM, Guzman AM, Chen CS, Fu W, Gudjonsson JE, McCormick TS, Ward NL: Keratinocyte overexpression of IL-17C promotes psoriasiform skin inflammation. J Immun 2013;190:2252-2262.
74 Kemeny L, Ruzicka T, Dobozy A, Michel G: Role of interleukin-8 receptor in skin. Int Arch Allergy Immunol 1994;104:317-322.

75 Skoglund C, Scheynius A, Holmdahl R, Van der Meide PH: Enhancement of DTH reaction and inhibition of the expression of class II transplantation antigens by in vivo treatment with antibodies against gamma-interferon. Clin Exp Immunol 1988;71:428-432.

76 Mosser DM, Edwards JP: Exploring the full spectrum of macrophage activation. Nat Rev Immunol 2008;8:958-969.

77 Wang CQ, Suarez-Farinas M, Nograles KE, Mimoso CA, Shrom D, Dow ER, Heffernan MP, Hoffman RW, Krueger JG: IL-17 induces inflammation-associated gene products in blood monocytes, and treatment with ixekizumab reduces their expression in psoriasis patient blood. J Invest Dermatol 2014;134: 2990-2993.

78 Wang H, Peters T, Kess D, Sindrilaru A, Oreshkova T, Van Rooijen N, Stratis A, Renkl AC, Sunderkotter C, Wlaschek M, Haase I, Scharffetter-Kochanek K: Activated macrophages are essential in a murine model for $\mathrm{T}$ cell-mediated chronic psoriasiform skin inflammation. J Clin Invest 2006;116:21052114.

79 Stratis A, Pasparakis M, Rupec RA, Markur D, Hartmann K, Scharffetter-Kochanek K, Peters T, van Rooijen N, Krieg T, Haase I: Pathogenic role for skin macrophages in a mouse model of keratinocyte-induced psoriasis-like skin inflammation. J Clin Invest 2006;116: 2094-2104.

80 Yawalkar N, Tscharner GG, Hunger RE, Hassan AS: Increased expression of IL-12p70 and IL-23 by multiple dendritic cell and macrophage subsets in plaque psoriasis. J Dermatol Sci 2009;54:99-105.

81 Sabat R, Philipp S, Hoflich C, Kreutzer S, Wallace E, Asadullah K, Volk HD, Sterry W, Wolk $\mathrm{K}$ : Immunopathogenesis of psoriasis. Exp Dermatol 2007;16:779-798.

82 Lin AM, Rubin CJ, Khandpur R, Wang JY, Riblett M, Yalavarthi S, Villanueva EC, Shah P, Kaplan MJ, Bruce AT: Mast cells and neutrophils release IL-17 through extracellular trap formation in psoriasis. J Immunol 2011; 187:490-500.

83 Zaba LC, Krueger JG, Lowes MA: Resident and 'inflammatory' dendritic cells in human skin. I Invest Dermatol 2009;129:302-308.

84 Lande R, Gregorio J, Facchinetti V, Chatterjee $\mathrm{B}$, Wang YH, Homey B, Cao W, Wang YH, Su B, Nestle FO, Zal T, Mellman I, Schroder JM, Liu YJ, Gilliet M: Plasmacytoid dendritic cells sense self-DNA coupled with antimicrobial peptide. Nature 2007;449:564-569.

85 Ganguly D, Chamilos G, Lande R, Gregorio J, Meller S, Facchinetti V, Homey B, Barrat FJ, Zal T, Gilliet M: Self-RNA-antimicrobial peptide complexes activate human dendritic cells through TLR7 and TLR8. J Exp Med 2009; 206:1983-1994.
86 Chamian F, Lowes MA, Lin SL, Lee E, Kikuchi T, Gilleaudeau P, Sullivan-Whalen M, Cardinale I, Khatcherian A, Novitskaya I, Wittkowski KM, Krueger JG: Alefacept reduces infiltrating $\mathrm{T}$ cells, activated dendritic cells, and inflammatory genes in psoriasis vulgaris. Proc Nat Acad Sci USA 2005;102:2075-2080.

87 Sumaria N, Roediger B, Ng LG, Qin J, Pinto R, Cavanagh LL, Shklovskaya E, Fazekas de St Groth B, Triccas JA, Weninger W: Cutaneous immunosurveillance by self-renewing dermal gammadelta T cells. J Exp Med 2011;208:505518.

88 Gray EE, Suzuki K, Cyster JG: Cutting edge: Identification of a motile IL-17-producing gammadelta $\mathrm{T}$ cell population in the dermis. J Immunol 2011;186:6091-6095.

89 Cai Y, Shen X, Ding C, Qi C, Li K, Li X, Jala VR, Zhang HG, Wang T, Zheng J, Yan J: Pivotal role of dermal IL-17-producing gammadelta $\mathrm{T}$ cells in skin inflammation. Immunity 2011;35:596-610.

90 Bouchaud G, Gehrke S, Krieg C, Kolios A, Hafner J, Navarini AA, French LE, Boyman O: Epidermal IL-15Ralpha acts as an endogenous antagonist of psoriasiform inflammation in mouse and man. J Exp Med 2013;210: 2105-2117.

91 Mabuchi T, Singh TP, Takekoshi T, Jia GF, Wu X, Kao MC, Weiss I, Farber JM, Hwang ST: CCR6 is required for epidermal trafficking of gammadelta- $\mathrm{T}$ cells in an IL-23-induced model of psoriasiform dermatitis. J Invest Dermatol 2013;133:164-171.

92 Christophers E: The immunopathology of psoriasis. Int Arch Allergy Immunol 1996; 110:199-206.

93 Gottlieb SL, Gilleaudeau P, Johnson R, Estes L, Woodworth TG, Gottlieb AB, Krueger JG: Response of psoriasis to a lymphocyte-selective toxin (DAB389IL-2) suggests a primary immune, but not keratinocyte, pathogenic basis. Nat Med 1995;1:442-447.

94 Ellis CN, Gorsulowsky DC, Hamilton TA, Billings JK, Brown MD, Headington JT, Cooper KD, Baadsgaard O, Duell EA, Annesley TM, et al: Cyclosporine improves psoriasis in a double-blind study. JAMA 1986;256:31103116.

95 Lee E, Trepicchio WL, Oestreicher JL, Pittman D, Wang F, Chamian F, Dhodapkar M, Krueger JG: Increased expression of interleukin 23 p19 and p40 in lesional skin of patients with psoriasis vulgaris. J Exp Med 2004;199: 125-130.

96 Narita M, Nishizawa Y, Iwaya S, Oiwa E, Iwabuchi M, Uchiyama T, Matsuyama A, Masuko M, Takahashi M: Ustekinumab improves psoriasis without suppressing tumor antigenspecific cytotoxic $\mathrm{T}$ lymphocytes. Int Arch Allergy Immunol 2014;165:52-60.

97 Park H, Li Z, Yang XO, Chang SH, Nurieva R, Wang YH, Wang Y, Hood L, Zhu Z, Tian Q, Dong C: A distinct lineage of CD4 T cells regulates tissue inflammation by producing interleukin 17. Nat Immunol 2005;6:11331141. 
98 Volpe E, Servant N, Zollinger R, Bogiatzi SI, Hupe P, Barillot E, Soumelis V: A critical function for transforming growth factor-beta, interleukin 23 and proinflammatory cytokines in driving and modulating human $\mathrm{T}(\mathrm{h})-17$ responses. Nat Immunol 2008;9: 650-657.

99 Rizzo HL, Kagami S, Phillips KG, Kurtz SE, Jacques SL, Blauvelt A: IL-23-mediated psoriasis-like epidermal hyperplasia is dependent on IL-17A. J Immunol 2011;186:14951502.

100 Cosmi L, Liotta F, Maggi E, Romagnani S, Annunziato F: Th17 and non-classic Th1 cells in chronic inflammatory disorders: two sides of the same coin. Int Arch Allergy Immunol 2014;164:171-177.

101 Wolk K, Haugen HS, Xu W, Witte E, Waggie $\mathrm{K}$, Anderson M, Vom Baur E, Witte K, Warszawska K, Philipp S, Johnson-Leger C, Volk HD, Sterry W, Sabat R: IL-22 and IL-20 are key mediators of the epidermal alterations in psoriasis while IL-17 and IFN-gamma are not. J Mol Med (Berl) 2009;87:523536.

102 Zheng Y, Danilenko DM, Valdez P, Kasman I, Eastham-Anderson J, Wu J, Ouyang W: Interleukin-22, a $\mathrm{T}(\mathrm{h}) 17$ cytokine, mediates IL-23-induced dermal inflammation and acanthosis. Nature 2007;445:648-651.

103 Van Belle $A B$, de Heusch M, Lemaire MM, Hendrickx E, Warnier G, Dunussi-Joannopoulos K, Fouser LA, Renauld JC, Dumoutier L: IL-22 is required for imiquimodinduced psoriasiform skin inflammation in mice. J Immunol 2012;188:462-469.

104 Krueger JG: Hiding under the skin: a welcome surprise in psoriasis. Nat Med 2012;18: 1750-1751.

105 Schlapbach C, Gehad A, Yang C, Watanabe $\mathrm{R}$, Guenova E, Teague JE, Campbell L, Yawalkar N, Kupper TS, Clark RA: Human Th9 cells are skin-tropic and have autocrine and paracrine proinflammatory capacity. Sci Transl Med 2014;6:219ra218.

106 Bedard K, Krause KH: The NOX family of ROS-generating NADPH oxidases: physiology and pathophysiology. Physiol Rev 2007; 87:245-313.

107 Hancock JT, Desikan R, Neill SJ: Role of reactive oxygen species in cell signalling pathways. Biochem Soc Trans 2001;29:345-350.

108 Zhou Q, Mrowietz U, Rostami-Yazdi M: Oxidative stress in the pathogenesis of psoriasis. Free Radic Biol Med 2009;47:891905.

109 Berendes H, Bridges RA, Good RA: A fatal granulomatosus of childhood: the clinical study of a new syndrome. Minn Med 1957; 40:309-312.

110 Quie PG, White JG, Holmes B, Good RA: In vitro bactericidal capacity of human polymorphonuclear leukocytes: diminished activity in chronic granulomatous disease of childhood. J Clin Invest 1967;46:668-679.
111 Baehner RL, Nathan DG: Leukocyte oxidase: defective activity in chronic granulomatous disease. Science 1967;155:835-836.

112 van den Berg JM, van Koppen E, Ahlin A, Belohradsky BH, Bernatowska E, Corbeel L, Espanol T, Fischer A, Kurenko-Deptuch M, Mouy R, Petropoulou T, Roesler J, Seger R, Stasia MJ, Valerius NH, Weening RS, Wolach B, Roos D, Kuijpers TW: Chronic granulomatous disease: the European experience. PLoS One 2009;4:e5234.

113 Matute JD, Arias AA, Wright NA, Wrobel I, Waterhouse CC, Li XJ, Marchal CC, Stull ND, Lewis DB, Steele M, Kellner JD, Yu W, Meroueh SO, Nauseef WM, Dinauer MC: A new genetic subgroup of chronic granulomatous disease with autosomal recessive mutations in $\mathrm{p} 40$ phox and selective defects in neutrophil NADPH oxidase activity. Blood 2009;114:3309-3315.

114 Wagener FA, Carels CE, Lundvig DM: Targeting the redox balance in inflammatory skin conditions. Int J Mol Sci 2013;14:91269167.

115 Ortonne JP: Aetiology and pathogenesis of psoriasis. Br J Dermatol 1996;135(suppl 49):1-5.

116 Raynaud F, Evain-Brion D, Gerbaud P, Marciano D, Gorin I, Liapi C, Anderson WB: Oxidative modulation of cyclic AMP-dependent protein kinase in human fibroblasts: possible role in psoriasis. Free Radic Biol Med 1997;22:623-632.

117 Turner CP, Toye AM, Jones OT: Keratinocyte superoxide generation. Free Radic Biol Med 1998;24:401-407.

118 Vignais PV: The superoxide-generating NADPH oxidase: structural aspects and activation mechanism. Cell Mol Life Sci: CMLS 2002;59:1428-1459.

119 Babior BM, Lambeth JD, Nauseef W: The neutrophil NADPH oxidase. Arch Biochem Biophys 2002;397:342-344.

120 Nauseef WM: Biological roles for the NOX family NADPH oxidases. J Biol Chem 2008; 283:16961-16965.

121 McCann SK, Roulston CL: NADPH oxidase as a therapeutic target for neuroprotection against ischaemic stroke: future perspectives. Brain Sci 2013;3:561-598.

122 Therond P, Gerbaud P, Dimon S, Anderson WB, Evain-Broin D, Raynaud F: antioxidant enzymes in psoriatic fibroblasts and erythrocytes. J Invest Dermatol 1996;106:13251328.

123 Yildirim M, Inaloz HS, Baysal V, Delibas N: The role of oxidants and antioxidants in psoriasis. J Eur Acad Dermatol Venereol 2003; 17:34-36.

124 Dogan P, Soyuer U, Tanrikulu G: Superoxide dismutase and myeloperoxidase activity in polymorphonuclear leukocytes and serum ceruloplasmin and copper levels in psoriasis. Br J Dermatol 1989;120:239-244.
125 Utas S, Kose K, Yazici C, Akdas A, Kelestimur F: Antioxidant potential of propylthiouracil in patients with psoriasis. Clin Biochem 2002;35:241-246.

126 Lee YS, Cheon IS, Kim BH, Kwon MJ, Lee HW, Kim TY: Loss of extracellular superoxide dismutase induces severe IL-23-mediated skin inflammation in mice. J Invest Dermatol 2013;133:732-741.

127 Baek JO, Byamba D, Wu WH, Kim TG, Lee MG: Assessment of an imiquimod-induced psoriatic mouse model in relation to oxidative stress. Arch Dermatol Res 2012;304: 699-706.

128 Pastore S, Mariani V, Lulli D, Gubinelli E, Raskovic D, Mariani S, Stancato A, de Luca C, Pecorelli A, Valacchi G, Potapovich AI, Kostyuk VA, Korkina LG: Glutathione peroxidase activity in the blood cells of psoriatic patients correlates with their responsiveness to efalizumab. Free Radic Res 2011; 45:585-599.

129 Seifert O, Holmberg J, Linnarsson BM: Decreased activity of neutrophil glutathione peroxidase in chronic plaque-type psoriasis. J Am Acad Dermatol 2007;57:528-529.

130 Polkanov VS, Bochkarev IuM, Shmeleva LT, Kipper SN: Lipid peroxidation and the blood antioxidant activity in psoriasis (in Russian). Vestn Dermatol Venerol 1987;7:42-46.

131 Kim H-R: Attenuation of experimental colitis in glutathione peroxidase 1 and catalase double knockout mice through enhancing regulatory T cell function. PLoS One 2014; $17: e 95332$.

132 Won HY, Sohn JH, Min HJ, Lee K, Woo HA, Ho YS, Park JW, Rhee SG, Hwang ES: Glutathione peroxidase 1 deficiency attenuates allergen-induced airway inflammation by suppressing Th2 and Th17 cell development. Antioxid Redox Signal 2010;13:575587.

133 Won HY, Jang EJ, Lee K, Oh S, Kim HK, Woo HA, Kang SW, Yu DY, Rhee SG, Hwang ES: Ablation of peroxiredoxin II attenuates experimental colitis by increasing FoxO1-induced Foxp3+ regulatory T cells. J Immunol 2013;191:4029-4037.

134 Rodrigues-Sousa T, Ladeirinha AF, Santiago AR, Carvalheiro H, Raposo B, Alarcao A, Cabrita A, Holmdahl R, Carvalho L, SoutoCarneiro MM: Deficient production of reactive oxygen species leads to severe chronic DSS-induced colitis in Ncf1/p47phox-mutant mice. PLoS One 2014;9:e97532.

135 Hultqvist M, Olofsson P, Holmberg J, Backstrom BT, Tordsson J, Holmdahl R: Enhanced autoimmunity, arthritis, and encephalomyelitis in mice with a reduced oxidative burst due to a mutation in the Ncf1 gene. Proc Nat Acad Sci USA 2004;101: 12646-12651.

136 Olofsson P, Holmberg J, Tordsson J, Lu S, Akerstrom B, Holmdahl R: Positional identification of $\mathrm{Ncf1}$ as a gene that regulates arthritis severity in rats. Nat Genet 2003;33: 25-32. 
137 Gelderman KA, Hultqvist M, Holmberg J, Olofsson P, Holmdahl R: T cell surface redox levels determine $\mathrm{T}$ cell reactivity and arthritis susceptibility. Proc Nat Acad Sci USA 2006;103:12831-12836.

138 Gelderman KA, Hultqvist M, Pizzolla A, Zhao M, Nandakumar KS, Mattsson R, Holmdahl R: Macrophages suppress T cell responses and arthritis development in mice by producing reactive oxygen species. J Clin Invest 2007;117:3020-3028.

139 Efimova O, Szankasi P, Kelley TW: Ncf1 (p47phox) is essential for direct regulatory $\mathrm{T}$ cell mediated suppression of CD4+ effector T cells. PLoS One 2011;6:e16013.

140 Kim H-R: Reactive oxygen species prevent imiquimod-induced psoriatic dermatitis through enhancing regulatory $\mathrm{T}$ cell function. PLoS One 2014;9:e91146.
141 Thom SR: Experimental use of hyperbaric oxygen therapy. J Emerg Med 1985;3:65.

142 Butler G, Michaels JC, Al-Waili N, Finkelstein M, Allen M, Petrillo R, Carrey Z, Kolanuvada B, Lee BY, Riera AG, Michaels CC, Urteaga G: Therapeutic effect of hyperbaric oxygen in psoriasis vulgaris: two case reports and a review of the literature. J Med Case Rep 2009;3:7023.

143 Furuhashi T, Saito C, Torii K, Nishida E, Yamazaki S, Morita A: Photo(chemo)therapy reduces circulating Th17 cells and restores circulating regulatory $\mathrm{T}$ cells in psoriasis. PLoS One 2013;8:e54895.
144 Briganti S, Wlaschek M, Hinrichs C, Bellei B, Flori E, Treiber N, Iben S, Picardo M, Scharffetter-Kochanek K: Small molecular antioxidants effectively protect from PUVA-induced oxidative stress responses underlying fibroblast senescence and photoaging. Free Radic Biol Med 2008;45:636-644.

145 Deffert C, Carnesecchi S, Yuan H, Rougemont AL, Kelkka T, Holmdahl R, Krause $\mathrm{KH}$, Schappi MG: Hyperinflammation of chronic granulomatous disease is abolished by NOX2 reconstitution in macrophages and dendritic cells. J Pathol 2012;228:341350.

146 Foerster J, Storch A, Fleischanderl S, Wittstock S, Pfeiffer S, Riemekasten G, Worm M: Neutrophil respiratory burst is decreased in scleroderma and normalized by near-infrared mediated hyperthermia. Clin Exp Dermatol 2006;31:799-806. 